\title{
Floral biology and breeding system of Psychotria tenuinervis Muell. Arg. (Rubiaceae) in the Atlantic rain forest, SE Brazil
}

\author{
Carolina Bernucci Virillo ${ }^{1}$, Flavio Nunes Ramos ${ }^{2}$, Cibele Cardoso de Castro ${ }^{3,4}$ and João Semir ${ }^{1}$
}

Received: November 30, 2006. Accepted: March 7, 2007

\begin{abstract}
RESUMO - (Biologia floral e sistema reprodutivo de Psychotria tenuinervis Muell. Arg. (Rubiaceae) na Floresta Atlântica, SE Brasil). O objetivo deste trabalho foi investigar a biologia de polinização, a morfometria floral, a proporção de morfos na população, e o sistema de cruzamentos de Psychotria tenuinervis em uma área de Mata Atlântica do SE, Brasil. A biologia da polinização foi estudada através de observações focais e o sistema de cruzamentos foi determinado usando cruzamentos controlados; dados de produção floral e morfometria floral foram comparados entre as duas formas florais. As duas formas florais apresentaram produção similar de flores, as quais são diurnas e hercogâmicas recíprocas. Ambas as formas florais são polinizadas por abelhas, com freqüência similar de visitas. O comprimento, o diâmetro da corola e o comprimento da antera foram similares entre as formas florais, porém os lobos estigmáticos foram maiores nas brevistilas. Psychotria tenuinervis é preferencialmente auto- e intramorfo incompatível, não apomítica e apresenta populações isopléticas. $\mathrm{Na}$ área de estudo, P. tenuinervis pode ser considerada uma espécie distílica típica, cujas flores hercogâmicas recíprocas parecem favorecer polinizações intermorfo e cruzamentos legítimos.
\end{abstract}

Palavras-chave: distilia, flor, hercogamia, mata Atlântica, polinização

ABSTRACT - (Floral biology and breeding system of Psychotria tenuinervis Muell. Arg. (Rubiaceae) in the Atlantic rain forest, SE Brazil). The aim of this study was to investigate pollination biology, floral morphometry, morph ratio and breeding system of Psychotria tenuinervis in an area of Atlantic rain forest in southeastern Brazil. Pollination biology was studied based on focal observations and the breeding system was determined using controlled crosses; data on flower production and floral morphometry were compared between the two floral morphs. Flower production by the two floral morphs was similar, with flowers being reciprocally herkogamous, diurnal and pollinated at similar frequencies, mainly by medium-sized bees. Corolla length and diameter, as well as anther length, were similar between the floral morphs, whereas stigma lobes were larger in thrums. Psychotria tenuinervis is a preferentially self- and intramorphincompatible, non-apomitic species, with isoplethic populations. At the study site, $P$. tenuinervis may be considered as a typical distylous species, with reciprocal herkogamous flowers that favour intermorph pollinations and legitimate matings.

Key words: Atlantic forest, distyly, flower, herkogamy, pollination

\section{Introduction}

The family Rubiaceae is represented by trees and mainly understory shrubs in many tropical forests, but is rare in temperate regions (Cronquist 1981; Burger \& Taylor 1993). This family shows a great variety of breeding (Bawa \& Beach 1983) and pollination syndromes, including pollination by butterflies (Hamilton 1990), moths (Nilsson et al. 1990), bees (Hamilton 1990) and birds (Sobrevilla et al. 1983; Ree 1997; Castro \& Araújo 2004). Among the 25 heterostylous Angiosperm families, the Rubiaceae has the greatest number of species with this floral mechanism (Barrett 1992): 416 species in 31 genera (Bahadur 1968 apud Jung-Mendaçolli \& Melhem 1995).

Heterostyly is a genetically controlled floral polymorphism with two morphological forms, namely, distyly and tristyly, that are characterized by two or three morphs, respectively. These morphs show variations in style and filament length, pollen grain size and production, and in the size of the stigmatic papillae and corolla. In addition, the morphs have an incompatibility system in which fruit are produced only

\footnotetext{
1 Universidade Estadual de Campinas, Instituto de Biologia, Departamento de Botânica, C. Postal 6109, 13083-970 Campinas, SP, Brazil

2 Universidade Federal de Alfenas, Departamento de Farmácia, Rua Gabriel Monteiro da Silva 714, Centro, 37130-000 Alfenas, MG, Brazil

3 Universidade Federal Rural de Pernambuco, Departamento de Biologia (Área de Botânica), Avenida Dom Manoel de Medeiros s.n., Dois Irmãos, 52171-900 Recife, PE, Brazil

4 Corresponding author: cibelecastro@hotmail.com
} 
in intermorph crosses (Barrett \& Richards 1990; Kohn \& Barrett 1992). Reciprocal herkogamy forces pollinators to contact same-level floral organs with the same region of their body, thereby producing legitimate (intermorph) pollination (Barrett \& Richards 1990; Dulberger 1992). This morphological (floral parts) and physiological (incompatibility system) convergence in distylous species provides an efficient mechanism that avoids selfing and maximizes male and female fitness (Lloyd \& Webb 1992). Differences in pollinator efficiency and the consequent pollen limitation for one of the morphs reduce the fecundity of heterostylous species (Eckert \& Barrett 1994; Arroyo \& Dafni 1995). These differences have been suggested to result from variations in the quantity and quality of flower visits, and, consequently, in the contact with anthers and stigma from different morphs.

Studies of tropical distylous species of Rubiaceae have revealed several cases of atypical distyly (sensu Barrett 1992), e.g., the absence of reciprocal herkogamy, isoplethic populations and/or incompatibility systems and monomorphy (Sobrevilla et al. 1983; Barrett \& Richards 1990; Hamilton 1990; Richards and Koptur 1993; Riveros et al. 1995; Pailler \& Thompson 1997). Several cases of atypical distyly in Rubiaceae species may be a consequence of changes in pollinator availability and/or behavior, and include the evolution of self-compatibility (Sobrevilla et al. 1983; Barrett 1992; Richards and Koptur 1993; Riveros et al. 1995; Ree 1997), fruit set biased toward one morph (Björkman 1995), dioecy (Beach and Bawa 1980; Pailler et al. 1998), homostyly (Charlesworth \& Charlesworth 1979; Sobrevilla et al. 1983), and the loss of reciprocal herkogamy and/or the secondary morphological features described above (Hamilton 1990; Dulberger 1992; Faivre \& McDade 2001).

The genus Psychotria contains about 2,000 species of shrubs, small trees and herbs, but rarely epiphytes, and is the largest genus in the family Rubiaceae (Davis et al. 2001). Most species of Psychotria are common in the understory of tropical and subtropical forests (Hamilton 1990; Taylor 1996; Mabberley 1997) and have small flowers that are pollinated by bees, flies, moths and birds (Hamilton 1990; Castro \& Araujo 2004). Despite the large number of Psychotria species, few studies have investigated heterostyly, pollination biology and reproduction in this genus. Others aspects that have been studied include the breeding system (Bawa \& Beach 1983; Lima 1988; Pérez-Nasser et al. 1993; Castro \& Oliveira 2004; Teixeira \& Machado 2004), variation in distyly (Hamilton 1990; Monteiro et al. 1991; Faivre \& McDade 2001), pollination efficiency (Stone 1995, 1996; Castro \& Oliveira 2002; Castro \& Araujo 2004; Ramos \& Santos 2006), reproductive phenology (Almeida \& Alvez 2000; Ramos \& Santos 2005) and reproductive biology (Coelho \& Barbosa 2004).

The objectives of this study were to investigate the pollination biology, floral morphometry, morph ratio and breeding system of Psychotria tenuinervis, a shrub commonly found in fragments of Atlantic rainforest in southeastern Brazil (Ramos \& Santos 2005; 2006).

\section{Material and methods}

Study area and species - The study was done in 2002 and 2003, in a 180 ha area located on the coast of the Serra do Palmital (22 $50^{\prime} \mathrm{S}$ and $\left.42^{\circ} 28^{\prime} \mathrm{W}\right)$, at Saquarema, in the state of Rio de Janeiro, Brazil. This area consists of about 1,200 ha of Atlantic forest at altitudes ranging from 30 to $400 \mathrm{~m}$, and has not been deforested, probably because the rough topography is inappropriate for cropland or cattle pasture. Psychotria tenuinervis Muell. Arg. is a non-clonal shrub, 1-5 m high that is typical of the Atlantic forest understory in the state of Rio de Janeiro, and is very abundant in the study area (Ramos \& Santos 2005; 2006). This species flowers during 2-4 months per year, whereas fruits are produced in almost all months (Ramos \& Santos 2005).

Floral biology and pollinators - All data were collected using individuals from a minimum of two plant populations. Individual flower production was estimated by counting the number of inflorescences and flowers/ inflorescence in 10 individuals of each morph (ten flowers/inflorescence, five inflorescences/individual). The period of anthesis was monitored for five days (six individuals/morph). The time of anthesis and stigmatic receptivity were recorded, with the latter being checked using the peroxidase technique (Dafni 1992) in three flowers/individual, three times a day (early morning, midday and late afternoon). Corolla length and diameter, and anther and stigma height and length were measured using digital calipers (error: $0.01 \mathrm{~mm}$ ) in fixed flowers (30 flowers/morph) collected from 10 plants of each morph. The floral morphometric data of the morphs were compared using Student's $t$-test (Sokal \& Rohlf 1981).

The profile of floral visitors was determined based on $67.5 \mathrm{~h}$ of observation on 15 plants. The observations were made during $10 \mathrm{~min}$ periods, from 7:00 $\mathrm{h}$ to 
16:00 $\mathrm{h}$, during which the visiting species, the number of visits, the behavior during visits, such as contact with anthers and stigma, the type of reward collected and the interactions with other visitors were recorded. At least one individual for each visiting species was collected for taxonomic identification (see Acknowledgements section).

Breeding system - The breeding system was investigated by comparing fruit production among handpollinated flowers. Inflorescences containing unopened flowers were enclosed in mesh bags for self-, intramorph- and intermorph-pollination experiments. Recently opened flowers were emasculated immediately before hand pollination, which was done by brushing a dehiscent anther across the stigma. Selfpollination was done using the flower's own pollen, and spontaneous self-pollination was tested by monitoring fruit production in untreated flowers enclosed in the bud stage. Fruit production after intramorph and intermorph pollination was tested using pollen from different individuals of the same morph and from an individual of the opposite morph, respectively. The natural fruit set was checked in marked flowers, and apomixis was tested in flowers emasculated in the pre-anthesis stage prior to enclosure in mesh bags. For each treatment, six individuals/morph and a minimum of 20 flowers were used. Buds were not emasculated (except those tested for apomixis) because the flowers were too small and this procedure could damage the stigma. Fruit production within and between the floral morphs was compared using the exact Fisher's test (Sokal \& Rohlf 1981).

\section{Results}

Psychotria tenuinervis flowered twice in 2002 (July and September) and only once in 2003 (November). The plants produced terminal inflorescences with a few tubular, white flowers, that had a pentalobed calyx and corolla (Fig. 1). The odorless flowers started to open at ca. 7:00 h, when their stigmas were receptive and pollen was available, and dropped off in late afternoon (17:00 h). Inflorescence and flower production were similar between the floral morphs $\left(\mathrm{t}_{18}=-0.27, \mathrm{p}=0.79\right.$ and $\mathrm{t}_{18}=18.5, \mathrm{p}=0.07$, respectively, Fig. 2).

Flowers were reciprocally herkogamous $\left(t_{134}=-1.9, p=0.05\right.$ for the lower level of sexual elements and $\mathrm{t}_{126}=1.9, \mathrm{p}=0.05$ for the higher level; Table 1). Corolla $\left(\mathrm{t}_{119}=2.4, \mathrm{p}=0.02\right)$, anther $\left(\mathrm{t}_{135}=2.2\right.$, $\mathrm{p}=0.03)$ and stigma lobe $\left(\mathrm{t}_{94}=15.1, \mathrm{p}=0.001\right)$ lengths were larger in thrums than in pins, although corolla diameter was similar between the two floral morphs $\left(\mathrm{t}_{134}=-0.12, \mathrm{p}=0.91\right)$.

The flowers of $P$. tenuinervis were legitimately visited by 11 insect species (Table 2), mainly between 09:00-10:00 $\mathrm{h}$ and 14:00-15:00 $\mathrm{h}$ when most of the floral visitors contacted anthers and stigma. Hymenopteran
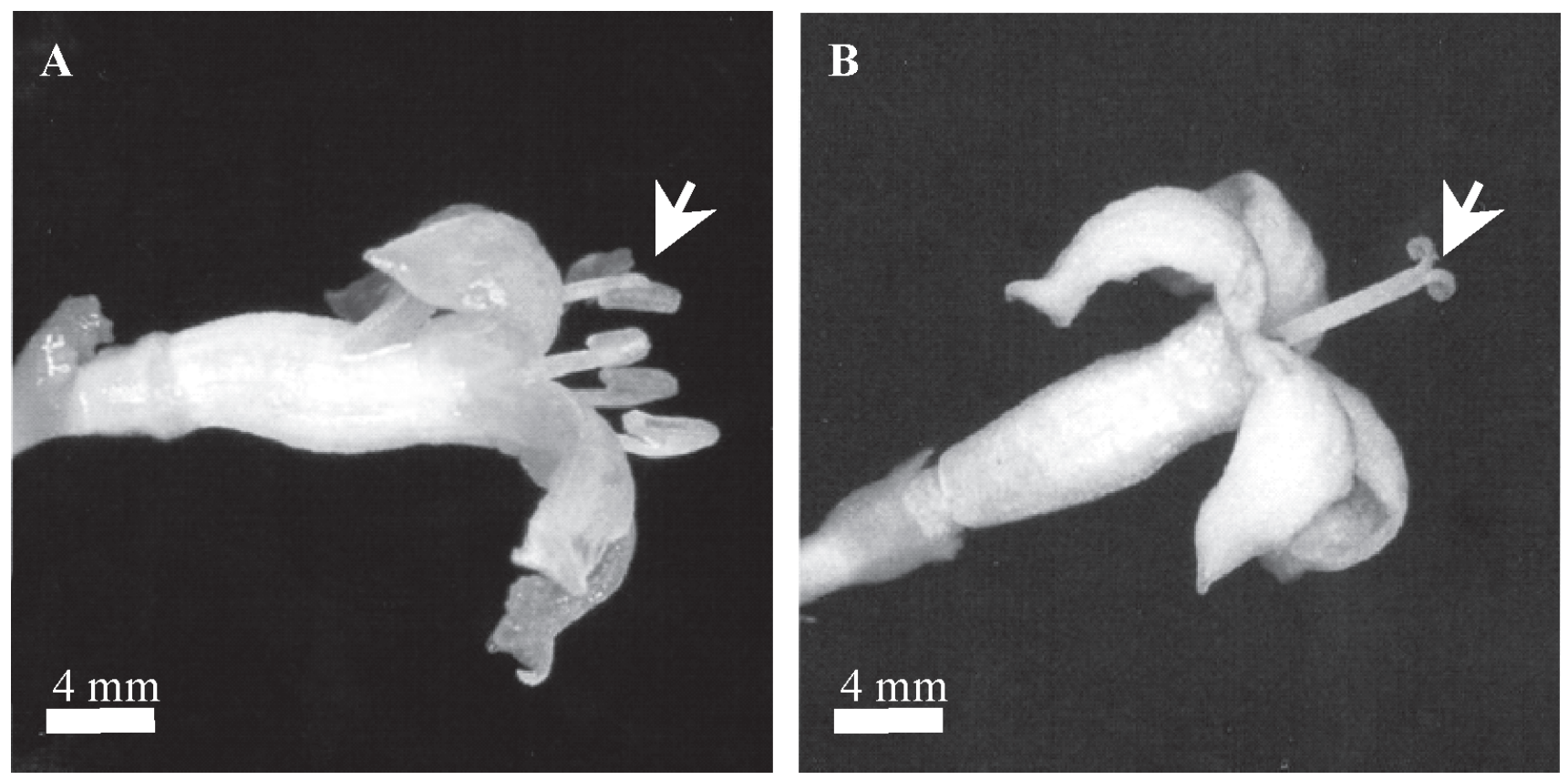

Figure 1. Thrum (A) and pin (B) flowers of Psychotria tenuinervis (Rubiaceae) in an area of Atlantic rain forest in southeastern Brazil. Arrows: anthers (in A) and stigma (in B). 


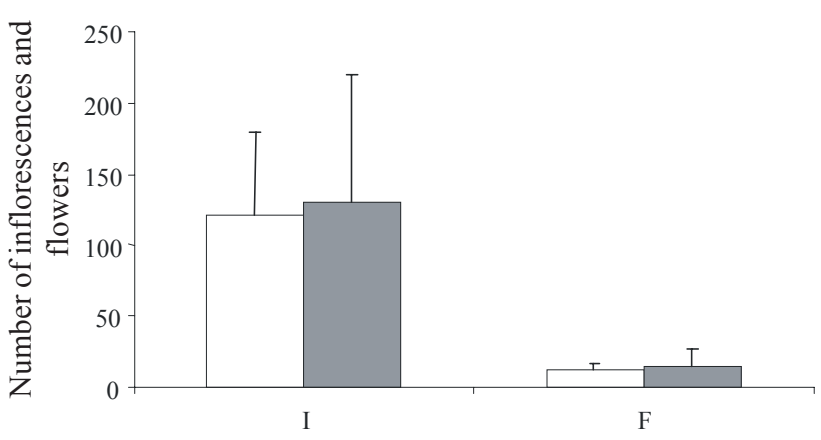

Figure 2. The number of inflorescences (I) and flowers per inflorescence (F) in thrum ( $\square$ ) and pin ( $\square$ ) flowers of Psychotria tenuinervis (Rubiaceae) in an area of Atlantic rain forest in southeastern Brazil. The columns represent the mean and standard deviation.

species were the most frequent visitors $(96.5 \%$ of all visits), followed by lepidopterans and dipterans (3\% and $0.5 \%$, respectively). The bees Apis mellifera (Linnaeus) and Trigona fulviventris (Guerin) were the most frequent species (Table 2). Trigona fulviventris and Partamona sp. bees robbed nectar through holes at the base of the corolla tube, but this behavior was not common. The frequency of visits was similar for the two floral morphs $\left(\chi_{1}^{2}=0.001 ; \mathrm{p}=0.99\right)$.

Breeding system - The fruit set that resulted from intermorph pollination was similar to that from natural (control) flowers within ( $\mathrm{p}=0.99$ for thrums, and $\mathrm{p}=0.24$ for pins $)$ and between $(\mathrm{p}=0.7114$ for thrums and $\mathrm{p}=0.4667$ for pins) floral morphs. The other (illegitimate) treatments produced a very low proportion of set fruits (Table 3), indicating that $P$. tenuinervis was preferentially a self- and intramorph-incompatible, non-apomitic species. The species population was isoplethic since the morph ratio did not differ significantly from 1:1 (148 thrums : 152 pins).

\section{Discussion}

Several features of $P$. tenuinervis such as the presence of diurnal, pale-colored flowers were similar to those frequently recorded and expected for
Table 2. Frequency of Psychotria tenuinervis (Rubiaceae) floral visitors in an area of Atlantic rain forest in southeastern Brazil.

\begin{tabular}{lc}
\hline Species & Visits (\%) \\
\hline Hymenoptera & \\
Apis mellifera (Apidae) & 52.8 \\
Trigona fulviventris (Apidae) & 29.3 \\
Partamona sp. (Apidae) & 10.4 \\
Centris sp. (Apidae) & 2.4 \\
Eulaema nigrita (Apidae) & 1.1 \\
Vespidae sp. 1 & 0.5 \\
Lepidoptera & \\
Melete lycimnia (Pieridae) & 1.3 \\
Urbanus dorantes (Hesperidae) & 1.1 \\
Eurema sp. (Pieridae) & 0.3 \\
Melete sp. (Pieridae) & 0.3 \\
Diptera & \\
Diptera sp. 1 & 0.5 \\
\hline
\end{tabular}

mellitophilous species, especially for species pollinated by small bees that usually collect nectar and/or pollen (Proctor et al. 1996). The absence of a perceptible scent indicated that the floral visitors were attracted visually to the flowers (Proctor et al. 1996). Studies on the pollination biology of distylous species have also recorded bees and butterflies as the main pollinators (Hamilton 1990; Castro \& Oliveira 2002), which corroborates the generally accepted idea that Rubiaceae species are pollinated mainly by hymenopterans and lepidopterans (Taylor 1996).

Small, sympetalous, tubular flowers, such as those of $P$. tenuivervis, are common in distylous species (Robbrecht 1988; Lloyd \& Webb 1992; Castro \& Oliveira 2002). This floral morphology is thought to force the visitors to the center of the flower, thereby maximizing pollen flow (Ganders 1979; Dulberger 1992). The reciprocal herkogamy seen in P. tenuinervis is the main morphological feature of distylous species (Faivre \& McDade 2001). Differences in corolla and anther size between floral morphs are uncommon in distylous species. However, when significant differences occur, thrums are generally larger than pins. In addition, the size of the

Table 1. Morphometrics of the floral traits of Psychotria tenuinervis (Rubiaceae) in an area of Atlantic rain forest in southeastern Brazil. Values, in $\mathrm{mm}$, are mean $\pm \mathrm{SD}$ of sample sizes shown in parentheses in the Morph column. $\mathrm{P}=$ pins, $\mathrm{T}=$ thrums.

\begin{tabular}{|c|c|c|c|c|c|c|}
\hline Morph & Stigma height & Lobe length & Anther height & Length & Corolla height & Diameter \\
\hline Т (69) & $5.6 \pm 0.54$ & $1.7 \pm 0.45$ & $8.4 \pm 0.76$ & $1.9 \pm 0.44$ & $6.5 \pm 0.46$ & $1.6 \pm 0.26$ \\
\hline$P(69)$ & $8.1 \pm 1.01$ & $0.8 \pm 0.21$ & $5.8 \pm 0.59$ & $1.7 \pm 0.41$ & $6.2 \pm 0.67$ & $1.6 \pm 0.29$ \\
\hline
\end{tabular}


Table 3. Fruit production (\%) after hand pollination experiments (number of flowers in parentheses) for Psychotria tenuinervis (Rubiaceae) in an area of Atlantic rain forest in southeastern Brazil. AP: apomixis, CO: control, CP: intermorph (cross)-pollination, IM: intramorph-pollination, SP: self-pollination.

\begin{tabular}{lccccc}
\hline Morph & CP & IM & SP & AP & CO \\
\hline Thrums & $16.6(30)$ & $0(20)$ & $0(20)$ & $0(20)$ & $16(25)$ \\
Pins & $9.4(32)$ & $0(20)$ & $5(20)$ & $0(20)$ & $23.8(21)$
\end{tabular}

stigma may also vary between morphs, such as seen in P. tenuinervis (Dulberger 1992, but see Castro \& Araujo 2004; Ree 1997; Richards \& Koptur 1993).

The larger floral parts in thrum flowers may compensate for an asymmetrical pollen flow compared to pin morphs since larger flowers may be more attractive than pin flowers (Dulberger 1992). Although several explanations have been proposed to explain the asymmetrical floral morphometrics of distylous species, the causes of this phenomenon are still poorly understood (Pailler \& Thompson 1997). The similar flower production of the two morphs suggested that both were equally attractive to floral visitors. Indeed, the floral visitors showed no preference for visiting a particular floral morph, indicating that they are potentially efficient pollinators for maintaining the population isoplethy.

Our results indicated that $P$. tenuinervis was a preferentially self- and intramorph-incompatible species because the fruit set did not differ between legitimately and naturally pollinated flowers, and there was almost no fruit production after illegitimate crosses, in agreement with most reports on the mating system of distylous species. These results, together with those for floral morphometrics and the morph ratio, indicated that, in the area studied, $P$. tenuinervis was a typical distylous species.

\section{Acknowledgements}

The authors thank Isabela A. dos Santos for identifying the bees, André V.L. Freitas for identifying the butterflies, M. Ueda for identifying the wasps, Arício $X$. Linhares for identifying the dipterans, Vanessa Rosseto and Maíra T. Ribeiro for valuable help with the field work and Stephen Hyslop for correcting the English. This work was supported by grant no. 02/11733-4 from Fundação de Amparo à Pesquisa do Estado de São Paulo.

\section{References}

Almeida, E.M. \& Alves, M.A. 2000. Fenologia de Pychotria nuda e P. brasiliensis (Rubiaceae) em uma área de floresta Atlântica no sudeste do Brasil. Acta Botanica Brasilica 14: 335-346.

Arroyo, J. \& Dafni, A. 1995. Variation in habitat, season, ower traits, and pollinators in dimorphic Narcissus tazetta L. (Amaryllidaceae) in Israel. New Phytologist 129: $135-145$.

Barrett, S.C. 1992. Heterostylous genetic polymorphisms: model systems for evolutionary analysis. Pp. 1-25. In: S.C.H. Barrett. Evolution and function of heterostyly. Springer-Verlag, Berlin.

Barrett, S.C. \& Richards, J. 1990. Heterostyly in tropical plants. Memoirs of The New York Botanical Garden 55: $35-61$.

Bawa, K.S. \& Beach, J.H. 1983. Self-incompatibility systems in the Rubiaceae of a tropical lowland wet forest. American Journal of Botany 70: 1281-1288.

Beach J.H. \& Bawa K.S. 1980. Role of pollinators in the evolution of dioecy from distyly. Evolution 34: 1138-1142.

Björkman, T. 1995. The effectiveness of heterostyly in preventing illegitimate pollinations in dish-shaped flowers. Sex Plant Reproduction 8: 143-146.

Burger, W.C. \& Taylor, C.M. 1993. Flora costaricensis. Fieldiana 33: 1-333.

Castro, C.C. \& Araujo, A.C. 2004. Distyly and sequential pollinators of Psychotria nuda (Rubiaceae) in the Atlantic rain forest, Brazil. Plant Systematics and Evolution 244: 131-139.

Castro, C.C. \& Oliveira, P.E. 2002. Pollination biology of distylous Rubiaceae in the Atlantic rain forest, SE Brazil. Plant Biology 4: 640-646.

Castro, C.C. \& Oliveira, P.E. 2004. Breeding system and floral morphometry of distylous Rubiaceae from the Atlantic rain forest, SE Brazil. Plant Biology 6: 755-760.

Charlesworth, D. \& Charlesworth, B. 1979. A model for the evolution of heterostyly. American Naturalist 114: 467-498.

Coelho, C.P. \& Barbosa, A.A.A. 2004. Biologia reprodutiva de Psychotria poeppigiana Muell. Arg (Rubiaceae) em uma mata de galeria. Acta Botanica Brasilica 18: 481-489.

Cronquist, A. 1981. An integrated system of classification of flowering plants. New York, Columbia University Press.

Dafni, A. 1992. Pollination ecology - a practical approach. Oxford, Oxford University Press.

Davis, A.P.; Bridson, D.; Jarvis, C. \& Govaerts, R. 2001. The typification and characterization of genus Psychotria L. (Rubiaceae). Botanical Journal of the Linnean Society 135: 35-42.

Dulberger, R. 1992. Floral polymorphisms and their functional significance in the heterostylous syndrome. Pp. 41-84. In: S.C.H. Barrett. Evolution and function of heterostyly. Berlin, Springer-Verlag. 
Eckert, C.G. \& Barrett, S.C.H. 1994. Inbreeding depression in partially self-fertilizing Decodon verticillatus (Lythraceae): population genetic and experimental analyses. Evolution 48: 952-964.

Faivre, A.E. \& McDade, L.A. 2001. Population-level variation in the expression of heterostyly in three species of Rubiaceae: does reciprocal placement of anthers and stigmas characterize heterostyly? American Journal of Botany 88: 841-853.

Ganders, F.A. 1979. The biology of heterostyly. New Zealand Journal of Botany 17: 607-635.

Hamilton, C.W. 1990. Variations in a distylous theme in mesoamerican Psychotria subgenus Psychotria (Rubiaceae). Memoirs of The New York Botanical Garden 55: 62-75.

Jung-Mendaçolli, S. \& Melhem, T. 1995. Grãos de pólen de espécies heterostílicas de Rubiaceae. Revista Brasileira de Botânica 18: 61-93.

Kohn, J.R. \& Barrett, S.C. 1992. Experimental studies on the functional significance of heterostyly. Evolution 46: 43-55.

Lima, H.A. 1988. Heterostilia em Psychotria leiocarpa Cham. \& Schl. (Rubiaceae). Boletim do Museu Nacional 76: 1-16.

Lloyd, D.G. \& Webb, C.J. 1992. The evolution of heterostyly. Pp. 151-178. In: S.C.H. Barrett. Evolution and function of heterostyly. Berlin, Springer-Verlag.

Mabberley, D.J. 1997. The plant book - a portable dictionary of vascular plants. New York, Cambridge University Press.

Monteiro, R.; Nakajima, J.N.; Ribeiro, J.E.L.S. \& Toledo, J.C. 1991. Morfologia e distribuição espacial das formas heterostílicas de Psychotria barbiflora DC. (Rubiaceae). Naturalia 16: 137-146.

Nilsson, L.A.; Petterson, B. \& Ranaivo, J. 1990. "Ixoroid" pollen presentation and pollination by small moths in the Malagasy treelet Ixora platythyrsa (Rubiaceae). Plant Systematics and Evolution 170: 161-175.

Pailler, T.; Humeau, L. \& Figier, J. 1998. Reproductive trait variation in the functionally dioecious and morphologically heterostylous island endemic Chassalia corallioides (Rubiaceae). Biological Journal of the Linnean Society 64: 297-313.

Pailler, T. \& Thompson, J.D. 1997. Distyly and variation in heteromorphic incompatibility in Gaertnera vaginata (Rubiaceae) endemic to La Reunion Island. American Journal of Botany 84: 315-317.
Pérez-Nasser, N.; Eguiarte, L.E. \& Piñero, D. 1993. Mating system and genetic structure of the distylous tropical tree Psychotria faxlucens (Rubiaceae). American Journal of Botany 80: 45-52.

Proctor, M.; Yeo, P. \& Lack, A. 1996. The natural history of pollination. London, Harper Collins.

Ramos, F.N. \& Santos, F.A.M. 2005. Phenology of Psychotria tenuinervis (Rubiaceae) in Atlantic forest fragments: regional and local scale. Canadian Journal of Botany 83: 1305-1316.

Ramos, F.N. \& Santos, F.A.M. 2006. Floral visitors and pollination of Psychotria tenuinervis (Rubiaceae): distance from the anthropogenic and natural edges of an Atlantic forest fragment. Biotropica 38: 383-389.

Ree, R.H. 1997. Pollen flow, fecundity, and adaptative significance of heterostyly in Palicourea padifolia (Rubiaceae). Biotropica 29: 298-308.

Richards, J.H. \& Koptur, S. 1993. Floral variation and distyly in Guettarda scabra L. (Rubiaceae). American Journal of Botany 80: 31-40.

Riveros, G.M.; Barría, O.R. \& Humaña, A.M.P. 1995. Selfcompatibility in distylous Hedyotis salzmanii (Rubiaceae). Plant Systematics and Evolution 194: 1-8.

Robbrecht, E. 1988. Tropical woody Rubiaceae. Opera Botanica Belgica 1: 1-271.

Sobrevilla, C.; Ramirez, N. \& Enrech, N.X. 1983. Reproductive biology of Palicourea fendleri and $P$. petiolaris (Rubiaceae) heterostylous shrubs of a tropical cloud forest in Venezuela. Biotropica 15: 161-169.

Sokal, R.R. \& Rohlf, F.J.F. 1981. Biometry. San Francisco, W.H. Freeman.

Stone, J.L. 1995. Pollen donation patterns in a tropical distylous shrub (Psychotria suerrensis; Rubiaceae). American Journal of Botany 82: 1390-1398.

Stone, J.L. 1996. Components of pollination effectiveness in Psychotria suerrensis: a tropical distylous shrub. Oecologia 107: 504-512.

Taylor, C.M. 1996. Overview of the Psychotrieae (Rubiaceae) in the Neotropics. Opera Botanica Belgica 7: 261-270.

Teixeira, L.A.G. \& Machado, I.C. 2004. Biologia da polinização e sistema reprodutivo de Psychotria barbiflora DC. (Rubiaceae). Acta Botanica Brasilica 18: $853-862$. 